\title{
Use of adductor pollicis muscle thickness in hospitalized or ambulatory patients: a systematic review
}

Brunna Gabrielly Ferreira da Silva Soares ${ }^{1}$

Andréa Pereira Vicentini²

Objective: to analyze the use of the Adductor Pollicis Muscle Thickness (APMT) as an anthropometric parameter and prognostic indicator in hospitalized or ambulatory patients. Method: systematic review carried out the Web of Science, SCOPUS and Lilacs databases. Results: Twenty-three studies were performed on critical, surgical, oncological, nephropathic and hepatopathic patients, collecting data on bibliographic reference, study site, objectives, number of patients, age group, methodology, main results and conclusion. APMT proved to be a good anthropometric parameter for evaluation of nutritional status in critical patients without edema, and surgical, oncological and nephropathic patients, but presented poor performance for diagnosis of malnutrition in hepatopathic patients. It was a good prognostic indicator for mortality in critical, nephropathic and oncological patients, and also a good predictor of hospitalization in nephropathic patients. There was an association with neurological complications in Hepatic Encephalopathy (HE) in the case of hepatophatic patients, but it was not a predictor of postoperative complications in surgical patients. Conclusion: APTM was considered a good anthropometric parameter in most clinical conditions, except in patients with liver disease and a good prognostic indicator for mortality in critical, oncological and nephropathic patients, and a predictor of neurological complications in HE. Further prognostic investigation, standardization of cutoff points and evaluation of sensitivity and specificity are required.

Descriptors: Hospitalization; Nutritional Assessment; Anthropometry; Prognosis; Malnutrition; Servicio Ambulatorio en Hospital.

\footnotetext{
1 Nutricionist.

2 PhD, Associate Professor, Faculdade de Ciências da Saúde, Universidade Federal da Grande Dourados, Dourados, MS, Brazil.
}

\section{How to cite this article}

Soares BGFS, Vicentini AP. Use of adductor pollicis muscle thickness in hospitalized or ambulatory patients: a systematic review. Rev. Latino-Am. Enfermagem. 2018;26:e2960. [Access DOI: http://dx.doi.org/10.1590/1518-8345.2045.2960.

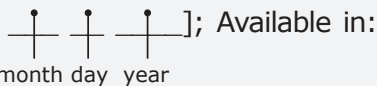




\section{Introduction}

Due to the limited use of sophisticated equipment for analysis of body composition in the clinical practice, for the high costs and the experience required in such procedures, anthropometric and laboratory parameters are still used for the nutritional assessment of hospitalized patients $^{(1)}$. Thus, new assessement methods are needed within the hospital environment, particularly those that are simple, relatively non-invasive, and that have high sensitivity and preserved specificity ${ }^{(2)}$.

In this context, a new assessment technique of the muscle compartment called Adductor Pollicis Muscle Thickness (APMT) was introduced in 2004 and it has been used to diagnose muscle loss and consequently, malnutrition ${ }^{(3,4)}$. The incidence of malnutrition lies between 20 and $69 \%$ in hospitalized patients, being higher in critical cases and nutritional levels ${ }^{(4,5)}$ that lead to increased muscle fatigue, loss of contraction force and relaxation rate of the adductor pollicis muscle (APM) $)^{(1,2)}$.

The opposition of the thumb is present in several activities of the daily life of humans. Since the APM is also consumed during catabolism and weakened when in disuse, its trophic condition can reflect the routine of an individual(1). This muscle can indicate changes in the muscle composition of the whole body, including early changes arising from both malnutrition and recovery of nutritional status ${ }^{(2,4)}$.

The technique to measure the APM was developed and published in 2004 and described as follows: the subject should be seated, with the right hand $(\mathrm{RH})$ on the knee and the elbow flexed at an angle of 90 degrees above the homolateral lower limb. The adipometer indicated by the researchers is the Lange $\AA$, which should be used with a continuous pressure of $10 \mathrm{~g} / \mathrm{mm}^{2}$. The evaluator pinches the adductor muscle located at the vertex of the imaginary triangle formed between the extension of the thumb and the index finger. This should be performed in triplicate to obtain a mean APM value. The reference values determined by the author serve to classify the degree of muscle loss in healthy individuals ${ }^{(1)}$.

The accuracy and reliability of anthropometric measures are influenced by many variables, such as: equipment, technical ability, cooperation of the individual, and variety of reference standards ${ }^{(2)}$. However, this new technique has many advantages; the APM is a muscle almost devoid of adipose tissue, flat, with a well-defined anatomic point, being the only one that allows the direct measurement of its thickness without need for calculations, and prone to quick, simple, noninvasive, low-cost measurement, easily reproducible by other researchers in both ambulatory and bedridden patients $(1,2,4,5)$. Thus, the objective of this study is to perform a systematic review on the use of APMT as an anthropometric parameter and prognostic indicator in hospitalized or ambulatory patients, when compared to other methods of assessment of nutritional status.

\section{Methods}

The following strategy was used for selection of descriptors and formulation of the guiding question of the systematic review. The group of patients named as "P" included hospitalized or ambulatory patients; the intervention "I" consisted in the application of the APMT; the comparison methods " $\mathrm{C}$ " were anthropometric and prognostic; and the expected outcome " $\mathrm{O}$ " was a good correlation between the evaluated variables. The guiding question of the research is: "Is the APMT a good anthropometric method and prognostic indicator compared to other methods used to evaluate nutritional status in hospitalized or ambulatory patients?" The following Health Sciences Descriptors were used (DeCS) to search scientific articles: "Hospitalização" OR "Avaliação nutricional" OR "Antropometria" OR "Prognóstico" OR "Desnutrição" OR "Ambulatório Hospitalar" combined with the term "Músculo adutor do polegar", which is not indexed in DeCS, and its English and Spanish translations "Hospitalization", "Hospitalización", "Nutritional Assessment", "Evaluación nutricional", "Anthropometry", "Antropometría", "Prognosis", "Pronosis" "Malnutrition", "Desnutrición", "Servicio Ambulatorio en Hospital"; "Hospital Outpatient Clinics", "Adductor pollicis muscle" and "Músculo aductor del pulgar".

The electronic databases used in the search for articles that are part of the systematic review of the scientific literature were the Web of Science (Thomsons Reuters), Scopus platform, and Latin American and Caribbean Literature in Health Sciences (Lilacs). The research and selection of articles were carried out by only one of the authors. Only articles duplicated in the databases were initially excluded. Then, eligibility criteria were adopted for the selection process, which began with the inclusion of studies that had applied the method of assessment of the APMT in hospitalized or ambulatory patients. After this step, titles and abstracts were read to select the texts that included the clinical conditions for the study presented in more than one article (critical, surgical, oncologic, nephropathic and hepathopatic patients), excluding articles with healthy patients, institutionalized elderly, hospitalized patients without pathological specifications, and patients with pathologies presented in only one article. 
A thorough reading of the selected studies was performed and the following data were collected: bibliographic reference, study site, objectives, number of evaluated patients, age range, methodology, main results and conclusion. These data were organized according to the clinical conditions abovementioned and later discussed along with the other important considerations reported in the researches. Full texts of articles of which only the abstract and title available were requested from the Federal University of Grande Dourados library, and those that were not found were excluded due to the inaccessibility to the statistical results. The last selection process excluded complete studies for the following reasons: insufficient results and lack of comparison with anthropometric variables and prognostic indicators.

The anthropometric variables considered for comparison were body mass index (BMI), arm circumference $(A C)$, arm muscle circumference (AMC), total arm area (TAA), arm muscle area (AMA), calf circumference (CC), triceps skinfold (TS), percentage weight loss, hand grip strength (HGS), electrical bioimpedance (EBI) [resistance, reactance, percentage of cell mass and phase angle (FA)] and Dual Energy X-ray Absorptiometry (DEXA). The variables considered with prognostic value for comparison were the Global Subjective Assessment (GSA), Sequential Organ Failure Assessment (SOFA), Glasgow prognostic score, length of hospital stay, days of mechanical ventilation, mortality, complications in the postoperative period (PP), risk of hospitalization, severity of the disease, serum albumin, serum creatinine and hemoglobin.

\section{Results}

Two hundred and twenty nine articles were initially searched, of which 165 were repeated and 64 were accessed. After the first selection by the criterion described in the methodology, 36 articles remained. The second selection (reading of the titles, abstracts and choice of articles of interest for research) resulted in 25 articles and the last step resulted in the final selection of 23 articles, 13 from the Web of Science, 6 from the Scopus Platform and 4 from the Lilacs. The studies included in the study were divided into five groups according to the following clinical conditions: critical ( $N=$ four), surgical ( $N=$ eight), hepathopatic $(N=$ five), oncological ( $\mathrm{N}=$ three) and nephropathic $(\mathrm{N}=$ three) patients. Steps for selection of articles are described in the Figure 1.
The following are the main results found in the studies conducted with critical patients and that evaluated APMT in both hands.

The first study was conducted in Cuiabá (MS) in 2012 and found that abnormal APMT (values below those found by other researchers) was associated with higher mortality $(p=0.03)$ and significantly correlated with the GSA outcomes for severe malnutrition ( $p<$ 0.001). Only patients without edema had a significant association between APMT measurement and length of hospital stay [APMT of RH without edema $(\beta=-0.32$, $p=0.03)$ and left hand without edema $(\beta=-0.36$, $p=0.02)$ ]. It was also observed that patients with abnormal APMT values had stayed in the intensive care unit (ICU) for approximately five days. There was no correlation between APMT and the number of days of mechanical ventilation. The values found were above those found in other studies, being higher in the $\mathrm{RH}$, what the author considered to be due to the presence of edema in the hands( ${ }^{(4)}$.

In 2015, a study carried out in Porto Alegre (RS) verified the accuracy of APMT by evaluating the Receiver Operating Characteristics (ROC) with the GSA (area under the curve regarding the $\mathrm{RH}$ of 0.82 and $95 \%$ confidence interval of 0.73 to 0.91 ). The study also related measures of less than $6.5 \mathrm{~cm}$ to higher nutritional risk in the GSA (moderately and severely malnourished). APMT of both hands was correlated with the BMI $(p<0.05$ and $r=0.45)$ and CC $(p<0.05$ $r=0.58)$; but not with length of hospital stay ( $p=$ $0.411)$ and mortality $(p=0.519)$. The study population consisted of $73.5 \%$ of elderly participants, which explains the low values found(3).

A study carried out in Asia in 2015 observed a significant difference in APMT measurements between races and genders $(p<0.05)$. No significant correlation was found with mortality at 28 days, hospital outcome, and ICU length of stay $(p>0.05)$. However, there was a significant and moderate correlation with AC and BMI ( $p$ $<0.05$ ), and APMT values were higher when compared to other Brazilian studies ${ }^{(2)}$. A study conducted in Iran found a strong correlation between APMT of both hands and all anthropometric variables evaluated, namely, TS, AC, AMC, ATB and AMA ( $p<0.0001)$, as well as serum albumin $(r=0.61, p=0.001)$. The measures of the dominant hand $(\mathrm{DH})$ presented positive correlation with ICU length of stay $(r=-0.4, p<0.001)$ and the highest correlation with mortality (odds ratio $3.8,95 \%$ confidence interval, 1.2 to $5.2, \mathrm{p}<0.01$ ). A significant correlation was also found between the dominant APMT and the SOFA score for organ failure $(r=-0.86, p<0.001)^{(5)}$. 


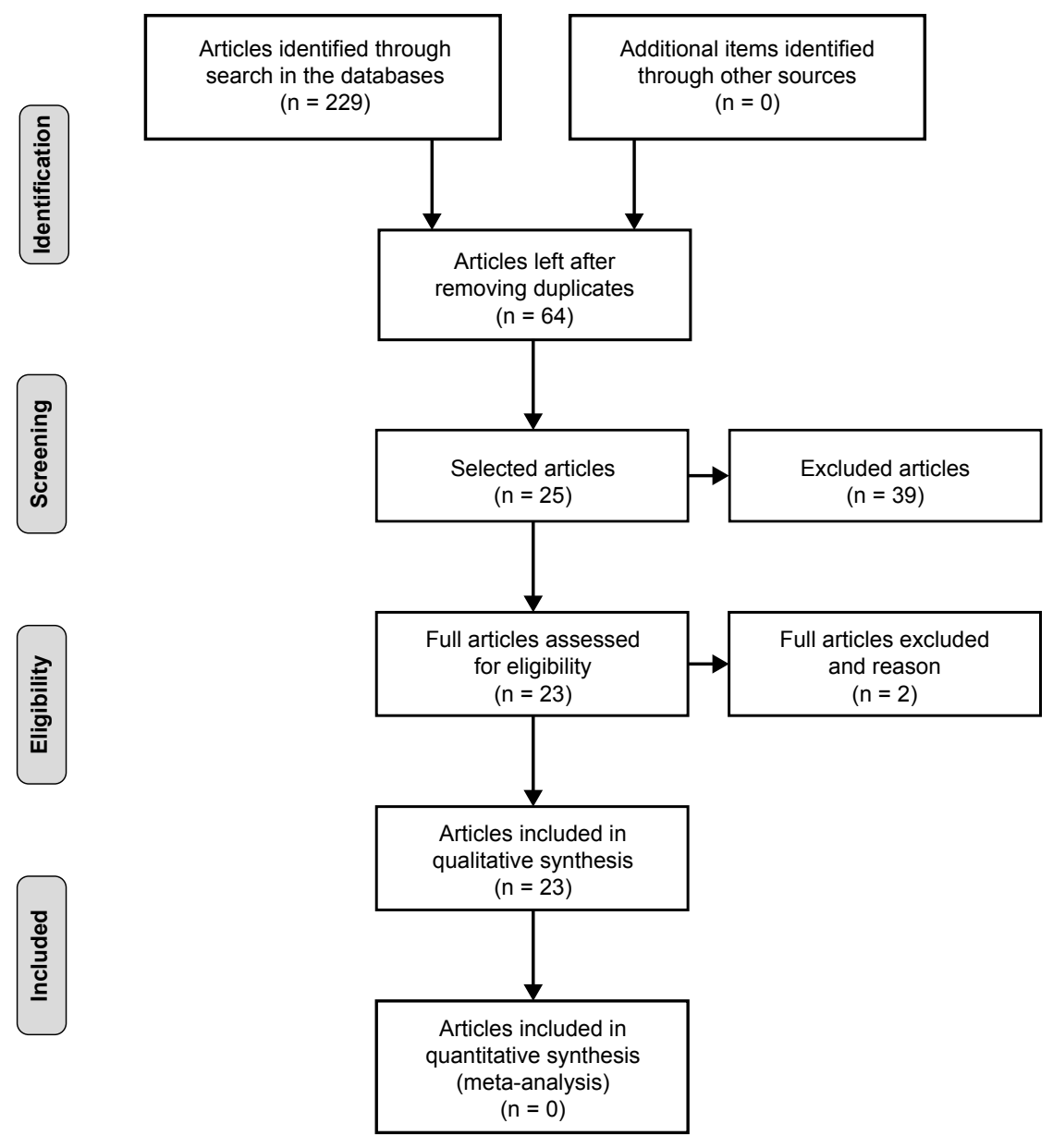

Figure 1 - Steps for selection of articles

\begin{tabular}{|c|c|c|c|}
\hline Objective & $\begin{array}{l}N^{\circ} \text { of patients } \\
\text { Age group years } \\
\text { Min-Max } \\
\text { (Mean } \pm S D) \\
\end{array}$ & $\begin{array}{l}\text { Objective and subjective } \\
\text { evaluations used to compare with } \\
\text { APMT* in both hands / Mean } \pm \text { SD }_{\text {and/or median of APMT }(\mathrm{mm})}\end{array}$ & Conclusion regarding APMT \\
\hline $\begin{array}{l}\text { To investigate whether APMT is a valid } \\
\text { prognostic indicator of morbidity and } \\
\text { mortality }{ }^{(4)} \text {. }\end{array}$ & $\begin{array}{l}246 \\
17-96 \\
(62)\end{array}$ & $\begin{array}{l}\mathrm{GSA}^{\dagger} \text {, ICU length of stay }{ }^{\ddagger} \text {, days of } \\
\text { mechanical ventilation, and mortality } \\
\text { / Mean } \mathrm{RH}^{\S}: 13.9 \pm 4.4 \text { and } \mathrm{LH}^{\|} \text {: } \\
12.8 \pm 4.3 \text {. }\end{array}$ & $\begin{array}{l}\text { APMT can be used as a prognostic indicator } \\
\text { in critically ill patients, as a fast, easy and } \\
\text { inexpensive method to estimate nutritional } \\
\text { status, especially lean body mass. It cannot } \\
\text { be considered an independent risk factor for } \\
\text { ICU length of stay and days of mechanical } \\
\text { ventilation. }\end{array}$ \\
\hline $\begin{array}{l}\text { To verify the relation of the APMT test } \\
\text { with GSA and to correlate it with other } \\
\text { anthropometric methods }{ }^{(3)} \text {. }\end{array}$ & $\begin{array}{l}83 \\
35-98 \\
(68.6)\end{array}$ & $\begin{array}{l}\text { GSA, BMI, CC }{ }^{* *} \text {, mortality and ICU } \\
\text { length of stay / Mean RH: } 8.03 \pm \\
2.98 \text { and LH: } 7.03 \pm 2.71 .\end{array}$ & $\begin{array}{l}\text { APMT proved to be a good and efficient method } \\
\text { for nutritional risk assessment. }\end{array}$ \\
\hline $\begin{array}{l}\text { To determine whether APMT can } \\
\text { be used as a predictive indicator of } \\
\text { mortality }^{(2)} \text {. }\end{array}$ & $\begin{array}{l}229 \\
(59.4 \pm 16.0)\end{array}$ & $\begin{array}{l}\text { AC, BMI, ICU length of stay and } \\
\text { mortality / Mean RH: } 20.4 \pm 6 \text { and } \\
\text { LH: } 19.9 \pm 6.1\end{array}$ & $\begin{array}{l}\text { APMT is not a universally applicable measure } \\
\text { and should be used with caution. }\end{array}$ \\
\hline $\begin{array}{l}\text { To determine if APMT correlates } \\
\text { with mortality, morbidity and other } \\
\text { anthropometric parameters }{ }^{(5)} \text {. }\end{array}$ & $\begin{array}{l}127 \\
(51.25 \pm 20.4)\end{array}$ & 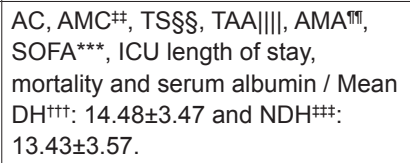 & $\begin{array}{l}\text { APMT was considered a valuable prognostic } \\
\text { indicator and a new low cost, reliable and easy } \\
\text { tool to assess the nutritional status of critically } \\
\text { ill patients. }\end{array}$ \\
\hline
\end{tabular}

Legend: *APMT - Adductor Pollicis Muscle Thickness; †GSA - Global Subjective Assessment; $¥$ ICU - Intensive Care Unit; §RH- Right Hand; IILeft Hand; १BMI- Body Mass Index; **CC - Calf Circumference; †+AC - Arm Circumference; キ¥AMC - Arm Muscle Circumference; §§TS - Triceps Skinfold; IIIITAA -

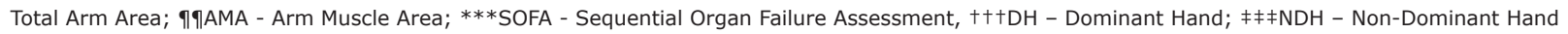

Figure 2 - Characteristics of the studies performed in critical patients 
Other studies evaluated surgical patients, three of which were performed with gastrointestinal (GIT) surgery patients, and the others with patients recovering from major surgeries and elective procedures.

In a research conducted in Rio de Janeiro (RJ) in 2005, APMT showed a significant correlation with septic complications in the PP in the case of patients with APMT values lower than $6.5 \mathrm{~mm}(p=0.007)$, as well as correlation with mechanical ventilation time $(p=0.000)$, ICU length of stay $(p=0.026)$, and significant tendency for hospital admission ( $p=0.053$ ). However, there was no significant association with nonseptic PP complications (area under the ROC curve of 0.562 and $p=0.305$ ) and mortality (area under the ROC curve of 0.641 and $p=0.217)^{(6)}$.

In the study carried out in Cuiabá (MT) in 2009, APMT was significantly correlated $(p<0.05)$ with all the anthropometric variables evaluated (BMI, AMC, AC, TS and percentage of weight loss) and had a good correlation with GSA values ( $p<0.05$ ), considered gold standard. In addition, it presented good sensitivity (72.37\% for APMT of the DH and $77.33 \%$ for that of $\mathrm{NDH}$ ) and $100 \%$ of specificity in both hands. The cutoff point for malnutrition was determined by the ROC curve, with $13.4 \mathrm{~mm}$ for the $\mathrm{DH}$ and $13.1 \mathrm{~mm}$ for the NDH. In the most recent study in 2011, there was an association between APMT and HGS (DH p $<0.001$; NDH $\mathrm{p}<$ $0.001)$ and mortality $(p<0.05)$. However, there was no significant association with length of hospitalization and complications in the PP (data not shown) ${ }^{(7,8)}$.

In a more recent study (2014) conducted in the same city, APMT did not show a good association with the percentage of weight loss $(p=0.113)$, AMC $(p=0.806)$ and AMAC $(p=0.770)$, but correlated significantly with $A C(p=0.003), T S(p=0.000)$ and BMI $(p=0.000)$. APMT was also associated with gender and age, as there was a high prevalence of malnutrition in women and the elderly. The values found in the $\mathrm{DH}$ were higher, suggesting a more rapid atrophy of this musculature in case of inactivity resulting from malnutrition ${ }^{(9)}$.

Study conducted in Pelotas (RS) published in 2015 identified an association and a significant linear trend between APMT values and GSA categories ( $p<0.001)$. It also found a strong association between APMT results for muscle mass depletion and GSA for malnutrition $(p<0.001)$. In this study, APMT showed low sensitivity (DH $34.9 \%$ and NDH 37.7\%), and high specificity (greater than 90\%) for predicting malnutrition ${ }^{(10)}$.

In the results of a research carried out in Vitória (ES) in 2016, APMT showed to be correlated with BMI, AMC, AMAc, CC $(p<0.01)$ and GSA $(p=0.026)$, with AMC ( $p=0.036)$ as the variable that most influenced APMT values(11). In a study carried out in the city of Salvador (BA) in the year of 2016, APMT did not present a significant association with the presence of complications in the PP in either hand ( $\mathrm{DH} p=0.217$ and NDH $\mathrm{p}=0.148)$. However, the APMT of the NDH was significantly associated with specific infectious complications $(p=0.030)^{(12)}$. In another study conducted in the same year in Recife (PE), APMT was compared to the gold-standard GSA method, but did not present a significant association ( $\mathrm{DH} \mathrm{p}=0.513$ and $\mathrm{NDH}$ $\mathrm{p}=0.842)^{(13)}$.

Data regarding the objectives, number of patients and age group, objective and subjective evaluations used for comparison with APMT and conclusion of the studies performed in surgical patients are described in the Figure 3.

Other studies were performed with oncological and nephropathic patients, being the first of them performed in 2012 in the city of Porto Alegre (RS), with cancer patients. The APMT values found in this study were associated with mortality $(p<0.001)$, however there was no association with length of hospital stay $(\mathrm{DH} p=0.42$ and NDH $p=0.43)^{(14)}$. Two studies carried out in Belo Horizonte (MG) in the year 2013 found the same result for APMT, which presented a significant difference between nourished and malnourished patients $(p<0.05)$, but a low agreement with the GSA $(\kappa<0.20)$; only one study had no association with the Glasgow prognostic score $(p>0.05)^{(15,16)}$. The next group includes nephropathic patients with Chronic Kidney Disease (CKD) undergoing dialysis and is described below. The study carried out in Fortaleza (CE) in the year 2012 followed patients for 12 months and found a significant difference and positive correlation between APMT and BMI $(r=0.37$; p 0.0001), AC ( $r=0.437 ; p<0.0001), A M C(r=0.494$; $p<0.0001)$, AMA $(r=0.449 ; p<0.0001)$, percentage of weight adequacy $(r=0.355 ; p=0.000)$, creatinine $(r=0.230 ; p=0.006)$, albumin $(r=0.207 ; p=0.013)$, percentage of body cell mass $(r=0.293 ; p=0.000)$ and FA ( $r=0.402 ; p<0.0001)$, and negative correlation with resistance measured by EBI ( $r=20.403 ; p<0.0001)$. However, no significant association was found with age, dialysis time, TS, hemoglobin, and reactance. Higher risks of hospitalization within six months and mortality were associated with lower APMT values ${ }^{(17)}$. A study carried out in São Paulo (SP) in the year of 2013 found APMT to be positively correlated with HGS ( $p<0.05)$, serum albumin ( $p=0.07)$, percentage of body cell mass $(p<0.05)$, reactance $(p<0.05)$ and FA $(p<0.05)$. However, APMT was not correlated with serum creatinine $(p=0.08), G S A(p=0.55)$ and the anthropometric measures BMI $(p=0.64), A C(p=0.62), A M C(p=0.70)$ and AMA ( $p=0.89)^{(18)}$. In 2014, in a study performed in a reference hospital in Rio Grande do Sul, APMT 
was associated with BMI ( $p=0.001)$, where higher values were more prevalent in overweight individuals and the lowest values in those with low weight ${ }^{(19)}$. The objectives, number of patients and age group, objective and subjective evaluations used for comparison with APMT and completion of the work with oncological and nephropathic patients are described in the Figure 4.

The last group of studies described was performed in nephropathic, mostly ambulatory, patients and conducted in the city of Porto Alegre. The first study was published in 2012 with ambulatory cirrhosis patients and found a low percentage of malnutrition (14.3\%) according to APMT measurement when compared to the HGS, TS, AC and AMC methods. APMT was not associated with disease severity and showed poor agreement with HGS methods [Kappa index $(\kappa)=0.12]$ and ASG $(\kappa=0.25)^{(20)}$. Another study found APMT to be significantly associated only with disease severity $(p<0.05)$, but also showed a low prevalence of malnutrition, a weak association with GSA ( $\kappa=0.222$ ) and no association with the diagnosis of malnutrition and inadequate dietary intake ${ }^{(21)}$. Two studies conducted in 2015 and 2016 with non-cirrhotic hepatitis $\mathrm{C}$ patients and patients before and after hepatic transplantation, respectively, did not identify any individuals with malnutrition and, therefore, APMT presented poor performance 22,23$)$.

In the year 2016, a study conducted in the city of Botucatu (SP) in cirrhotic patients with Hepatic Encephalopathy (HE) related APMT to disease severity, so that the reduction of $1 \mathrm{~mm}$ in the measurement was associated with an increase of $30.7 \%$ in the degree of HE $(p=0.0177)$. The lower values were related to lower states of mental acuity, since measures lower than the cutoff point $(6.5 \mathrm{~mm})$ were associated with the degrees I and II of HE $(p=0.013)^{(24)}$.

Data regarding the objectives, number of patients and age group, objective and subjective evaluations used for comparison with APMT, as well as the conclusion of the studies performed in hepatopathic patients are described in the Figure 5.

\begin{tabular}{|c|c|c|c|}
\hline Objective & $\begin{array}{l}N^{\circ} \text { of patients } \\
\text { Age group years } \\
\text { Min-Max } \\
\text { (Mean } \pm S D \text { ) }\end{array}$ & $\begin{array}{l}\text { Objective and subjective } \\
\text { evaluations used for comparison } \\
\text { with APMT* / Mean } \pm \text { SD and/or } \\
\text { median of APMT ( } \mathrm{mm})\end{array}$ & Conclusion regarding APMT \\
\hline $\begin{array}{l}\text { To evaluate APMT as a prognostic indicator } \\
\text { in patients submitted to valve heart surgery }{ }^{(6)} \text {. }\end{array}$ & $\begin{array}{l}99 \\
18-83 \\
(50.3 \pm 16)\end{array}$ & $\begin{array}{l}\text { Complications, mortality, length } \\
\text { of hospital length of stay and ICU } \\
\text { length of stay† and mechanical } \\
\text { ventilation / Mean } \mathrm{AM}^{\ddagger}: 9.54 \pm 2.5 \text {. }\end{array}$ & $\begin{array}{l}\text { APMT was not considered a superior } \\
\text { prognostic indicator, neither the other } \\
\text { parameters evaluated. }\end{array}$ \\
\hline $\begin{array}{l}\text { To determine if APMT measurement is } \\
\text { reliable for nutritional evaluation and to check } \\
\text { its correlation with other anthropometric, } \\
\text { biochemical and clinical parameters }{ }^{(7)} \text {. }\end{array}$ & $\begin{array}{l}87 \\
18-82 \\
(53.8 \pm 15.9)\end{array}$ & $\begin{array}{l}\mathrm{BMI}^{\S}, \mathrm{AC}^{\|}, \mathrm{AMC}^{\Uparrow}, \mathrm{TS}^{* *}, \mathrm{GSA}^{\dagger \dagger} \text {, } \\
\text { percentage weight loss and serum } \\
\text { albumin / Mean } \mathrm{DH}^{+\neq}: 12.64 \pm 3.19 \\
\text { and } \mathrm{NDH}^{\S \S}: 12.23 \pm 2.9 .\end{array}$ & $\begin{array}{l}\text { APMT is an easy-to-apply, low cost, } \\
\text { reliable and safe tool for nutritional } \\
\text { assessment in clinical practice with } \\
\text { surgical patients. }\end{array}$ \\
\hline $\begin{array}{l}\text { To evaluate whether APMT and HGSIIII } \\
\text { are reliable prognostic indicators of the } \\
\text { postoperative evolution of major surgeries of } \\
\text { the gastrointestinal tract }{ }^{(8)} \text {. }\end{array}$ & $\begin{array}{l}90 \\
(53 \pm 16)\end{array}$ & $\begin{array}{l}\text { BMI, AC, AMC, TS, HGS, mortality, } \\
\text { complications and length of } \\
\text { hospitalization. }\end{array}$ & $\begin{array}{l}\text { APMT was considered safe for nutritional } \\
\text { assessment in surgical patients and a } \\
\text { reliable prognostic indicator in the PPाT. }\end{array}$ \\
\hline $\begin{array}{l}\text { To estimate the prevalence of malnutrition } \\
\text { based on APMT, through cutoff points for } \\
\text { surgical patients suggested in the literature }{ }^{(9)} \text {. }\end{array}$ & $\begin{array}{l}151 \\
(51.91 \pm 15.78)\end{array}$ & $\begin{array}{l}\text { BMI, AC, AMC, TS, AMAc }{ }^{* \star *}, \\
\text { percentage of weight loss and } \\
\text { clinical diagnosis. }\end{array}$ & $\begin{array}{l}\text { APMT was considered a good method for } \\
\text { the diagnosis of both muscular depletion } \\
\text { and malnutrition in surgical patients. }\end{array}$ \\
\hline $\begin{array}{l}\text { To investigate the validity of APMT as a } \\
\text { nutritional parameter in surgical patients } \\
\text { through comparison with the GSA }{ }^{(10)} \text {. }\end{array}$ & $\begin{array}{l}361 \\
(49.6 \pm 17.8)\end{array}$ & BMI and GSA. & $\begin{array}{l}\text { APMT was associated with nutritional } \\
\text { status and considered a useful and easily } \\
\text { accessible tool to confirm malnutrition. }\end{array}$ \\
\hline $\begin{array}{l}\text { To evaluate the correlation between APMT } \\
\text { and anthropometric measurements, BMI and } \\
\text { GSA in the nutritional diagnosis of surgical } \\
\text { patients }^{(11)} \text {. }\end{array}$ & $\begin{array}{l}150 \\
(42.7 \pm 12.0)\end{array}$ & $\begin{array}{l}\text { BMI, AMC, TS, AMAc, } \mathrm{CC}^{+t+} \text { and } \\
\text { GSA. }\end{array}$ & $\begin{array}{l}\text { APMT is a reliable measure able to } \\
\text { identify the risk of malnutrition and may } \\
\text { be included in the nutritional screening } \\
\text { of surgical patients to facilitate nutritional } \\
\text { diagnosis. }\end{array}$ \\
\hline $\begin{array}{l}\text { To investigate the clinical complications in the } \\
\text { PP of elective cardiac surgeries }{ }^{(12)} \text {. }\end{array}$ & $\begin{array}{l}72 \\
(52.2 \pm 14.5)\end{array}$ & $\begin{array}{l}\text { Complications in the PP / Mean DH: } \\
11.4 \pm 3.4 \text { and NDH: } 11.2 \pm 3.5 \text {. }\end{array}$ & $\begin{array}{l}\text { APMT was associated with infectious } \\
\text { complications in the PP. }\end{array}$ \\
\hline $\begin{array}{l}\text { To evaluate through GSA the nutritional } \\
\text { status of surgical patients, comparing it } \\
\text { with nutritional screening and objective } \\
\text { methods }^{(13)} \text {. }\end{array}$ & $\begin{array}{l}46 \\
(56.24 \pm 14.38)\end{array}$ & $\begin{array}{l}\text { GSA / Mean DH: } 16.98 \pm 2.80 \text { and } \\
\mathrm{NDH}: 15.55 \pm 3.07\end{array}$ & APMT showed no association with GSA. \\
\hline
\end{tabular}

Legend: *APMT - Adductor Pollicis Muscle Thickness; +ICU - Intensive Care Unit; ¥BH - Both Hands; §BMI- Body Mass Index; IIAC - Arm Circumference; IAMC - Arm Muscle Circumference; **TS - Triceps Skinfold; †+GSA - Global Subjective Assessment; ‡¥DH- Dominant Hand; §§ Non-dominant hand; IIIIHGS - Hand Grip Strength; IIPP - Postoperative Period; ***AMAc - Arm Muscle Area corrected; ††+CC - Calf Circumference

Figure 3 - Characteristics of studies performed in surgical patients 


\begin{tabular}{|c|c|c|c|}
\hline Objective & $\begin{array}{l}N^{\circ} \text { of patients } \\
\text { Age group years } \\
\text { Min - Max (average } \\
\pm \text { SD) }\end{array}$ & $\begin{array}{l}\text { Objective and subjective } \\
\text { evaluations used for comparison } \\
\text { with APMT* / Mean } \pm \text { SD and/or } \\
\text { median of APMT (mm) }\end{array}$ & Conclusion regarding APMT \\
\hline $\begin{array}{l}\text { To evaluate the preoperative nutritional } \\
\text { status of patients with tumor in the upper } \\
\mathrm{GIT}^{\dagger} \text { and to indicate which methods } \\
\text { correlate with hospitalization and } \\
\text { mortality }{ }^{(14)} \text {. }\end{array}$ & $\begin{array}{l}74 \\
34-83 \\
(63 \pm 10.2)\end{array}$ & $\begin{array}{l}\text { Mortality and length of } \\
\text { hospitalization / Mean } \mathrm{DH}^{\ddagger}: 12.9 \pm \\
3.5 \text { and NDH§: } 12.0 \pm 3.6 \text {. }\end{array}$ & $\begin{array}{l}\text { APMT was determined as a reliable } \\
\text { predictor of mortality in patients } \\
\text { undergoing upper GIT tumor resection } \\
\text { surgeries. }\end{array}$ \\
\hline $\begin{array}{l}\text { To perform nutritional assessment by } \\
\text { GSAll and Glasgow score, and to verify its } \\
\text { relation with assessment methods }{ }^{(15)} \text {. }\end{array}$ & $\begin{array}{l}43 \\
(64.7 \pm 12)\end{array}$ & GSA, Glasgow prognostic score. & $\begin{array}{l}\text { APMT was considered a useful } \\
\text { parameter for classification of nutritional } \\
\text { status of cancer patients. }\end{array}$ \\
\hline $\begin{array}{l}\text { To correlate the nutritional status, the } \\
\text { Glasgow score and the complications of } \\
\text { anticancer treatment, besides associating } \\
\text { the GSA with other methods of nutritional } \\
\text { assessment }{ }^{(16)} \text {. }\end{array}$ & $\begin{array}{l}70 \\
(\text { Men: } 60.1 \pm 14) \\
(\text { Women: } 60.7 \pm 14.8)\end{array}$ & GSA. & $\begin{array}{l}\text { APMT showed low agreement with the } \\
\text { GSA. }\end{array}$ \\
\hline $\begin{array}{l}\text { To analyze the correlation between } \\
\text { anthropometric, biochemical and EBI } \\
\text { methods and evaluate the relationship } \\
\text { between APMT and mortality and } \\
\text { hospitalization }{ }^{(17)} \text {. }\end{array}$ & $\begin{array}{l}143 \\
(52.2 \pm 16.6)\end{array}$ & $\begin{array}{l}\mathrm{BMI}^{\star *}, \mathrm{TS}^{\dagger \dagger}, \mathrm{AMC}^{\ddagger \ddagger}, \mathrm{AMA}^{\S \S}, \mathrm{EBI} \text {, } \\
\text { percentage of weight adequacy, } \\
\text { biochemical tests, dialysis time, risk } \\
\text { of hospitalization and death / Mean } \\
\mathrm{BH}^{\mathrm{III}:} 11.85 \pm 1.62 \text { and Median } \mathrm{BH} \text { : } \\
12 .\end{array}$ & $\begin{array}{l}\text { APMT was considered a valid method to } \\
\text { diagnose malnutrition, predict the risk of } \\
\text { hospitalization and mortality in patients } \\
\text { with CKD }{ }^{\text {Tा }} \text { undergoing } \mathrm{HD}^{* * *} \text {. }\end{array}$ \\
\hline $\begin{array}{l}\text { To observe the behavior of APMT as a } \\
\text { nutritional indicator in patients undergoing } \\
\mathrm{HD}^{(18)} \text {. }\end{array}$ & $\begin{array}{l}73 \\
(52.3 \pm 17)\end{array}$ & $\begin{array}{l}\text { BMI, AC }{ }^{\dagger+t}, \text { TS, AMC, AMA, EBI, } \\
\text { HGS } \neq \pm \neq, \text { GSA, biochemical exams / } \\
\text { Mean BH: } 10 \pm 4.5 \text { and Median BH: } \\
10 .\end{array}$ & $\begin{array}{l}\text { APMT assumed HG and was suggested } \\
\text { as a indicator of nutritional status in } \\
\text { hemodialytic patients. }\end{array}$ \\
\hline $\begin{array}{l}\text { To analyze the nutritional status of } \\
\text { patients undergoing HD and the } \\
\text { associated factors }^{(19)} \text {. }\end{array}$ & $\begin{array}{l}90 \\
21-83 \\
(53.52 \pm 16.34)\end{array}$ & BMI / Mean BH: $11.9 \pm 3.07$. & APMT was associated with BMI. \\
\hline
\end{tabular}

Legend: *APMT - Adductor Pollicis Muscle Thickness ; +GIT - Gastrointestinal Tract; キDH - Dominant Hand; §MND - Non-Dominant Hand; IIGSA- Global Subjective Assessment; ๆEBI - Electrical Bioimpedance; **BMI - Body Mass Index; ††TS - Triceps Skinfold; ‡¥AMC - Arm Muscle Circumference; §§AMA -

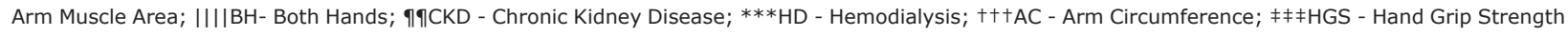

Figure 4 - Characteristics of the studies performed in oncological and nephropathic patients

\begin{tabular}{|c|c|c|c|}
\hline Objective & $\begin{array}{l}N^{\circ} \text { of patients } \\
\text { Age group } \\
\text { years } \\
\text { Min - Max } \\
\text { (average } \pm S D \text { ) }\end{array}$ & $\begin{array}{l}\text { Objective and subjective } \\
\text { evaluations used for } \\
\text { comparison with APMT* } \\
\text { / Mean } \pm \text { SD and/or } \\
\text { median of APMT (mm) }\end{array}$ & Conclusion regarding APMT \\
\hline $\begin{array}{l}\text { To compare different nutritional assessment } \\
\text { methods for diagnosis of malnutrition in } \\
\text { cirrhotic patients }^{(20)} \text {. }\end{array}$ & $\begin{array}{l}119 \\
(56 \pm 12)\end{array}$ & $\begin{array}{l}\mathrm{TS}^{\dagger}, \mathrm{AC}^{\ddagger}, \mathrm{AMC}^{\S}, \mathrm{HGS} \| \\
\mathrm{GSA}^{\top} \text { and disease severity. }\end{array}$ & $\begin{array}{l}\text { APMT was poorly associated with GSA and HGS } \\
\text { methods, and was not associated with disease } \\
\text { severity. }\end{array}$ \\
\hline $\begin{array}{l}\text { To calculate dietary intake and compare } \\
\text { various nutritional assessment methods } \\
\text { in chronic, cirrhotic and non-cirrhotic } \\
\text { hepatophatic patients }^{(21)} \text {. }\end{array}$ & $\begin{array}{l}97 \\
(52.8 \pm 10.1)\end{array}$ & $\begin{array}{l}\text { GSA, HGS and disease } \\
\text { severity. }\end{array}$ & $\begin{array}{l}\text { APMT had a poor performance in the diagnosis of } \\
\text { malnutrition. }\end{array}$ \\
\hline $\begin{array}{l}\text { To carry out an evaluation of the nutritional } \\
\text { status of non-cirrhotic hepatitis } C \text { patients } \\
\text { by comparing several methods and dietary } \\
\text { assessment }{ }^{(22)} \text {. }\end{array}$ & $\begin{array}{l}94 \\
30-76\end{array}$ & $\begin{array}{l}\mathrm{BMI}^{* *}, \mathrm{TS}+, \mathrm{AC}, \mathrm{AMC} \\
\mathrm{AMA}+, \mathrm{HGS}, \mathrm{GSA} / \\
\text { Mean } \mathrm{BH}^{++}: 16.6 \pm 2.5\end{array}$ & $\begin{array}{l}\text { APMT did not present a good performance in the } \\
\text { diagnosis of malnutrition. }\end{array}$ \\
\hline $\begin{array}{l}\text { To assess the nutritional status of cirrhotic } \\
\text { patients before and after liver transplantation } \\
\text { during one year of follow-up using various } \\
\text { methods and compare the results } \\
\text { (23). }\end{array}$ & $\begin{array}{l}32 \\
(57.3 \pm 7.9)\end{array}$ & $\begin{array}{l}\text { BMI, TS, AC, AMC, HGS } \\
\text { and FA§§. }\end{array}$ & $\begin{array}{l}\text { APMT presented low sensitivity and was considered } \\
\text { inappropriate for the follow-up of pre and post-liver } \\
\text { transplantation patients. }\end{array}$ \\
\hline $\begin{array}{l}\text { To relate HGS methods, body composition and } \\
\text { HE|||| degree in cirrhotic patients }{ }^{(24)} \text {. }\end{array}$ & $\begin{array}{l}54 \\
(56.9 \pm 11)\end{array}$ & $\begin{array}{l}\text { BMI, TS, AMC, AMAc }{ }^{\pi \pi,} \\
\text { HGS, DEXA }{ }^{* * *} \text { and } \\
\text { disease severity and } \mathrm{HE} \\
\text { stage / Median } \mathrm{BH}^{\neq \neq:} 7.1 \text {. }\end{array}$ & $\begin{array}{l}\text { APMT was considered a good indicator of cirrhotic } \\
\text { complications, as it was associated with the } \\
\text { neurological manifestations of } \mathrm{HE} \text {. }\end{array}$ \\
\hline
\end{tabular}

Legend: *APMT - Adductor Pollicis Muscle Thickness; † TS - Triceps Skinfold; ₹ AC - Arm Circumference; § AMC - Arm Muscle Circumference; II HGS Hand Grip Strength; ๆ GSA - Global Subjective Assessment; **BMI - Body Mass Index; †+AMA - Arm Muscle Area; $\neq \neq B H$ - Both Hands; IIIIHE - Hepatic Encephalopathy; १ीAMAc - Arm Muscle Area corrected; ***DEXA - Dual Energy X-ray Absorptiometry

Figure 5 - Characteristics of the studies performed in hepatopathic patients 


\section{Discussion}

APMT showed to be a good anthropometric parameter in critically ill patients without edema(3-5), which may be justified by the greater expression of critical and acute conditions in the ICU, protein depletion and muscle loss caused by both the decrease in daily activities and the hypercatabolic status of these patients ${ }^{(25)}$. APMT was also considered a good prognostic indicator for mortality in this group ${ }^{(4,5)}$, being efficient even in patients with hand edema in one of the studies ${ }^{(4)}$, although it was not considered as a good prognosis for ICU length of stay ${ }^{(2-4)}$. Perhaps, this may be explained by the fact that APMT evaluates the lean mass and whose preservation is an indication of good evolution in such patients, since malnutrition contributes to increased mortality (25). No justification was reported as to the usefulness as a good indicator for the ICU length of stay, but we believe that other clinical conditions are more determinant for the hospital stay.

The limitations found in the studies included in this review were the interdiction of the adductor pollicis muscle area, and especially the presence of edema that diminishes the accuracy of the APMT measurement and, therefore, led to the exclusion of many patients, compromising the application of this measure in the practice. Thus, the researchers suggest that this measure must becarefully evaluated and applied before the onset of edema, ideally on the first day of ICU admission and analyzed in conjunction with the other anthropometric and GSA methods ${ }^{(2,5)}$. The combination of several tools may be more efficient to detect abnormality in the body composition of these patients ${ }^{(3)}$.

In the group of individuals submitted to surgeries, APMT also proved to be a good method for nutritional evaluation and diagnosis of malnutrition, but it was not considered a good prognostic factor for the prevalence of complications in the PP. Malnutrition in these patients is associated with surgical stress, as this procedure promotes the release of catabolic hormones that cause the degradation of muscle proteins, which is aggravated according to the nutritional deficit of the patient $^{(9)}$. Thus, the potential detection of malnutrition can be justified by the good specificity of APMT verified in the studies, a characteristic that indicates a low rate of false positive results ${ }^{(7,10)}$. Furthermore, there is a correlation of APMT with anthropometric measures that happens due to the similar nature of the measures ${ }^{(7)}$. As for the non-association with PP complications, it is assumed that this result comes from the variability of this condition in function of the underlying disease severity and nutritional status prior to surgery.
In the evaluation of cancer patients, APMT was considered a good parameter for classification of nutritional status, but had low association with $\mathrm{GSA}^{(15,16)}$. This finding was indicated by the fact that GSA detected early functional alterations, while APMT detected malnutrition and changes in body composition only in later instance ${ }^{(15,16)}$. Only one study evaluated APMT as a prognostic indicator and found it to be a good parameter of mortality, resulting from its high discriminative power ${ }^{(14)}$.

With regard to nephropathic patients, APMT was also considered a good method of nutritional assessment compared to anthropometric parameters ${ }^{(17,19)}$ and a good predictor of hospitalization and mortality in the only study that evaluated its prognostic indication ${ }^{(17)}$, but the number of studies with this group is still small $(17,18)$. This outcome is based on the peculiarities of CKD patients, namely, reduced food intake and metabolic acidosis combined with uremia, factors that lead to protein catabolism $^{(19)}$, which along with physical inactivity, further aggravates the disease ${ }^{(17)}$. Furthermore, malnutrition is per se a risk factor for death in hemodialysis patients ${ }^{(17)}$.

However, studies evaluating hepatopathic patients revealed poor performance of APMT in the diagnosis of malnutrition, and only one showed an association with neurological complications in $\mathrm{HE}$. Two studies differed in relation to the severity of the disease. Non-association of APMT with malnutrition can be explained by fluid retention(24), low sensitivity demonstrated by the method(23) and anatomical muscle alteration that follows functional changes ${ }^{(21)}$.

An association of APMT with HE complications and disease severity was observed, most likely explained by the marked depletion of arm muscle experienced by cirrhotic patients ${ }^{(24)}$. The study in which there was no association with disease severity was justified by the low number of patients in the severe stage ${ }^{(20)}$.

GSA is present in almost half of the studies comparing different measures with APMT results. GSA is set as the gold standard by the American Society of Parenteral and Enteral Nutrition (ASPEN) for evaluation of hospitalized patients, and it is frequently used for validation of new methods ${ }^{(8,25)}$. GSA evaluates the nutritional status as a whole, including anthropometric, clinical, physical, metabolic and dietary data, identifying suspected or established malnutrition before changes in body composition. Thus, GSA presents the best prediction for arising complications; however, its efficacy depends on the ability of the evaluator to detect significant nutritional changes. This have led to the need to study new, simpler and less invasive methods to speed up the nutritional screening process ${ }^{(10,11,15,25)}$.

Among the ten studies comparing GSA with APMT, seven found a positive association between them and 
only three did not find association. Among the groups where association was detected are the surgical $(7,10,11)$, critical $^{(3,4)}$ and oncological ${ }^{(15,16)}$ patients, and those where association was absent were studies with surgical(13), nephropathic ${ }^{(18)}$ and hepatopathic ${ }^{(20)}$ patients.

Studies with healthy individuals were excluded from this review because they aimed to establish reference values for this population ${ }^{(26,27)}$, and the research with institutionalized elderly people analyzed their nutritional profile, but not its effectiveness compared to other methods. It is important to emphasize that in the latter group, all patients presented values within the normal range for healthy people and more studies are therefore necessary for the purpose of comparison ${ }^{(28)}$.

The greatest limitation observed in this review regarding the evaluation of APMT measurement was the absence of reference standards for the different clinical conditions, according to gender and age group. The values often referred to in the studies come from healthy populations or are defined based on a single cutoff point, and consequently may underestimate malnutrition in adults and in men, and overestimate it in the elderly and women $^{(8)}$. Another limitation found in the researched literature was the use of different adipometers and the standardization of the technique itself, which may have led to very different APMT values, besides the variability stemming from different evaluators ${ }^{(2,11)}$.

Minimum and maximum mean APMT values $(\mathrm{mm})$ were, respectively, $7.03 \pm 2.71(\mathrm{LH})$ and $20.4 \pm 6(\mathrm{RH})$ in critically ill patients ${ }^{(2-5)} ; 12.0 \pm 3.6(\mathrm{NDH})$ and $12.9 \pm$ $3.5(\mathrm{DH})$ in cancer patients ${ }^{(14)} ; 10 \pm 4.5(\mathrm{BH})$ and 11.9 $\pm 3.07(\mathrm{BH})$ in nephropathic patients ${ }^{(17-19)} ; 9.54 \pm 2.5$ $(\mathrm{BH})$ and $16.98 \pm 2.80(\mathrm{RH})$ in surgical patients $(6,7,12,13)$; and $16.6 \pm 3.5$ and a median of 7.1 in hepatopathic patients ${ }^{(22,24)}$. However, these data refer to only 14 studies that provided such values. Yet, it is interesting to note that the lowest APMT values were found in a study with critical patients (7.03 \pm 2.71 in the left hand) (3) and in hepatopathic patients (median of $7.1 \mathrm{~mm}$ in both hands) (24).

Thus, it is necessary to determine specific cutoff points for pathologies or groups of individuals and carefully interpret the results. It is also necessary to assess the actual sensitivity and specificity of APMT. In this sense, sensitivity is a parameter that evaluates the probability of the result to be positive, and specificity analyzes the probability of that same result to be negative(29).

\section{Conclusion}

APMT was considered a good anthropometric parameter in the great majority of clinical conditions evaluated, except in patients with liver disease, and presented low sensitivity and high specificity. It was also indicated as a good prognostic indicator for mortality in critical, oncological and renal patients, and as a predictor of neurological complications in hepatic encephalopathy. However, further investigation of its prognostic usefulness in other clinical conditions, standardization of cutoff points for reference in the measurement classification and assessment of sensitivity and specificity is required.

\section{Acknowledgments}

To the Professors Rita de Cassia Bertolo Martins and Verônica Gronau Luz for the suggestions for improvement of the study after reading the first version.

\section{References}

1. Lameu EB, Gerude MF, Corrêa RC, Lima KA. Adductor pollicis muscle: a new anthropometric parameter. Rev Hosp Clin Fac Med Sao Paulo [Internet]. 2004 [cited June 1, 2017];59(2):57-62. Available from: http:// www.scielo.br/scielo.php?script $=$ sci_arttext\&pid=S004187812004000200002B doi: http://dx.doi.org/10.1590/ S0041-87812004000200002

2. Shu-Fen $C L$, Ong $V$, Kowitlawakul $Y$, Ling $T A$, Mukhopadhyay A, Henry J. The adductor pollicis muscle: a poor predictor of clinical outcome in ICU patients. Asia Pac J Clin Nutr. [Internet] 2015 [cited June 1, 2017];24(4):605-9. Available from: http://apjcn. nhri.org.tw/server/APJCN/24/4/605.pdf doi: 10.6133/ apjen.2015.24.4.22.

3. Karst FP, Vieira RM, Barbiero S. Relação da espessura do músculo adutor do polegar e avaliação subjetiva global em unidade de terapia intensiva cardiológica. Rev Bras Ter Intensiva. [Internet]. 2015;27(4):36975 [Acesso 1 jun 2017]. Disponível em: http://www. scielo.br/scielo.php?script $=$ sci_arttext\&pid=S0103507X2015000400369

doi: http://dx.doi.org/10.5935/0103-507X.20150062

4. Caporossi FS, Caporossi C, Borges Dock-Nascimento D, Aguilar-Nascimento JE. Measurement of the thickness of the adductor pollicis muscle as a predictor of outcomes in critically ill patients. Nutr Hosp. [Internet] 2012 [cited June 1, 2017];27(2):490-5. Available from:http:// scielo.isciii.es/scielo.php?script $=$ sci_arttext\&nrm $=$ iso \&lng $=p t \& t \operatorname{lng}=p t \& p i d=S 0212-16112012000200021$ doi: $10.3305 / \mathrm{nh} .2012 .27 .2 .5514$

5. Ghorabi S, Ardehali H, Amiri Z, Shariatpanahi ZV. Association of the Adductor Pollicis Muscle Thickness with Clinical Outcomes in Intensive Care Unit Patients. Nutr Clin Pract. [Internet] 2016 [cited June 1, 2017];31(4):5236. Available from: https://www.ncbi.nlm.nih.gov/ pubmed/26869610 doi: 10.1177/0884533615621547 
6. Andrade FN, Lameu EB, Luiz RR. Musculatura Adutora do Polegar: um novo índice prognóstico em cirurgia cardíaca valvar. Rev SOCERJ. [Internet]. 2005;18(5):384-91 [Acesso 1 jun 2017]. Disponível em: http://pesquisa.bvsalud.org/portal/resource/pt/lil428673

7. Bragagnolo R, Caporossi FS, Dock-Nascimento DB, Aguilar-Nascimento JE. Espessura do músculo adutor do polegar: um método rápido e confiável na avaliação nutricional de pacientes cirúrgicos. Rev Col Bras Cir. [Internet]. 2009;36(5):371-6 [Acesso 1 jun 2017]. Disponível em: http://www.scielo.br/scielo.php?script=sci_arttex t\&pid=S0100-69912009000500003 doi: http://dx.doi. org/10.1590/S0100-69912009000500003

8. Bragagnolo R, Caporossi FS, Dock-Nascimento DB, Aguilar-Nascimento JE. Handgrip strength and adductor pollicis muscle thickness as predictors of postoperative complications after major operations of the gastrointestinal tract. e-SPEN, Eur E J Clin Nutr Metab. [Internet] 2011 [cited June 1, 2017];6:e21-e26. Available from:

http://e-spenjournal.org.marlin-prod.literatumonline.com/article/S1751-4991(10)00063-6/fulltext doi: http://dx.doi.org/10.1016/j.eclnm.2010.11.001

9. Melo CYSV, Silva SA. Músculo adutor do polegar como preditor de desnutrição em pacientes cirúrgicos. ABCD Arq Bras Cir Dig. [Internet]. 2014;27(1):13-7 [Acesso 2 jun 2017]. Disponível em: http://www.scielo.br/pdf/ abcd/v27n1/pt_0102-6720-abcd-27-01-00013.pdf doi: http://dx.doi.org/10.1590/S0102-67202014000100004 10. Gonzalez MC, Duarte RRP, Orlandi SP, Bielemann RM, Barbosa-Silva TG. Adductor pollicis muscle: A study about its use as a nutritional parameter in surgical patients. Clin Nutr. [Internet] 2015 [cited June 1, 2017];34:10259. Available from: http://www.clinicalnutritionjournal. com/article/S0261-5614(14)00270-2/pdf doi: http:// dx.doi.org/10.1016/j.clnu.2014.11.006

11. Valente KP, Silva NMF, Faioli $A B$, Barreto MA, Moraes RAG, Guandalini VR. Espessura do músculo adutor do polegar na avaliação nutricional de pacientes cirúrgicos. Einstein. [Internet]. 2016;14(1):18-24 [Acesso 1 jun 2017]. Disponível em: http://www.scielo.br/pdf/eins/ v14n1/pt_1679-4508-eins-14-1-0018.pdf

doi: http://dx.doi.org/10.1590/S1679-45082016AO3596

12. Gonçalves LB, Jesus NMT, Gonçalves MB, Dias LCG, Deiró TCBJ. Preoperative nutritional status and clinical complications in the postoperative period of cardiac surgeries. Braz J Cardiovasc Surg. [Internet] 2016 [cited June 1, 2016]:36(2):10-19. Available from: http://www. bjcvs.org/pdfRBCCV/v31n5a08.pdf doi:10.5935/16789741.20160077

13. Hanush FD, Silva MGD, Prado LVS, Costa MDS, Gadelha PCFP. Avaliação nutricional de pacientes submetidos à cirurgia do trato gastrointestinal: associação entre avaliação subjetiva global, ferramentas de triagem nutricional e métodos objetivos. Nutr Clín Diet Hosp. [Internet]. 2016;36(2):10-19 [Acesso 1 jun 2016]. Disponível em: http://revista.nutricion.org/PDF/ daysa.pdf doi 10.12873/362daysa

14. Poziomyck AK, Weston AC, Lameu EB, Cassol OS, Coelho LJ, Moreira LF. Preoperative Nutritional Assessment and Prognosis in Patients with Foregut Tumors. Nutr Cancer. [Internet] 2012 [cited June 1, 2017];64(8):117481. Available from: http://www.tandfonline.com/doi/abs/ 10.1080/01635581.2012.721157 doi: http://dx.doi.org/ 10.1080/01635581.2012.721157

15. Silva JB, Maurício SF, Bering T, Correia MITD. The relationship between nutritional status and the Glasgow prognostic score in patients with cancer of the esophagus and stomach. Nutr Cancer. [Internet] 2013 [cited June 1, 2017];65:25-33. Available from: https://www.ncbi. nlm.nih.gov/pubmed/23368910 doi: http://dx.doi.org/1 $0.1080 / 01635581.2013 .741755$

16. Mauricio SF, Silva JB, Bering T, Correia MITD. Relationship between nutritional status and the Glasgow Prognostic Score in patients with colorectal cancer. Nutrition. [Internet] 2013 [cited June 1, 2017];29:62529. Available from: http://www.nutritionjrnl.com/ article/S0899-9007(12)00372-3/pdf

doi: http://dx.doi.org/10.1016/j.nut.2012.09.016

17. Oliveira CMC, Kubrusly M, Mota RS, Choukroun G, Neto JB, Silva CAB. Adductor Pollicis Muscle Thickness: A Promising Anthropometric Parameter for Patients With Chronic Renal Failure. J Ren Nutr. [Internet] 2012 [cited June 1, 2017];22(3):307-16. Available from: http:// www.jrnjournal.org/article/S1051-2276(11)00149-X/ pdf doi: http://dx.doi.org/10.1053/j.jrn.2011.07.006 18. Pereira RA, Caetano AL, Cuppari L, Kamimura MA. Espessura do músculo adutor do polegar como preditor da força de preensão manual nos pacientes em hemodiálise. J Bras Nefrologia. [Internet]. 2013;35(3):177-84 [Acesso 2 jun 2017]. Disponível em: http://www.scielo.br/pdf/jbn/v35n3/v35n3a03.pdf doi: http://dx.doi.org/10.5935/0101-2800.20130029 19. Dobner T, Telles CT, Pomatti G, Pasqualotti A, Bettinelli LA. Avaliação do estado nutricional em pacientes renais crônicos em hemodiálise. Sci Med. [Internet]. 2014;24(1):11-8 [Acesso 2 jun 2017]. Disponível em: http://revistaseletronicas.pucrs.br/ojs/ index.php/scientiamedica/article/view/15858/11155 20. Nunes FF, Fernandes AS, Bertolini CM, Rabito EI, Gottschall CBA. Avaliação nutricional do paciente cirrótico: comparação entre diversos métodos. Sci Med. (Porto Alegre). [Internet]. 2012;22(1): 12-7 [Acesso 1 jun 2017]. Disponível em: http://revistaseletroni- 
cas.pucrs.br/ojs/index.php/scientiamedica/article/ view/9143/7515

21. Gottschall CBA, Nunes FF, Aydos MED, Bragança AC, Felix DR, Rabito EI, et al. Contribution of dynamometry and the Royal Free Hospital global assessment to the nutritional assessment of patients with chronic liver diseases. Rev Chil Nutr. [Internet] 2012 [cited June 2, 2017];39(4):152-8. Available from: http://www. scielo.cl/pdf/rchnut/v39n4/art07.pdf doi: http://dx.doi. org/10.4067/S0717-75182012000400007

22. Gottschall CBA, Pereira TG, Rabito EI, Álvares-DaSilva MR. Nutritional status and dietary intake in noncirrhotic adult chronic hepatitis c patients. Arq Gastroenterol. [Internet] 2015 [cited June 1, 2017];52(3): 204-9. Available from: http://www.scielo.br/pdf/ag/ v52n3/0004-2803-ag-52-03-204.pdf doi: http://dx.doi. org/10.1590/S0004-28032015000300010

23. Aydos MED, Fernandes SA, Nunes FF, Bassani L, Leonhardt LR, Harter $D L$, et al. One-year follow-up of the nutritional status of patients undergoing liver transplantation. Nutr Hosp. [Internet] 2016 [cited June 1, 2017];33(1): 8-13. Available from: http://scielo.isciii. es/pdf/nh/v33n1/03_original2.pdf doi: http://dx.doi. org/10.20960/nh.86

24. Augusti L, Franzoni LC, Santos LAA, Lima TB, Ietsugu MV, Koga $\mathrm{KH}$, et al. Lower values of handgrip strength and adductor pollicis muscle thickness are associated with hepatic encephalopathy manifestations in cirrhotic patients. Metab Brain Dis. [Internet] 2016 [cited June 1, 2017];31: 909-15. Available from: http://link.springer.com/article/10.1007\%2Fs11011-016-9828-8 doi: 10.1007/s11011-016-9828-8

25. Caporossi FS, Bragagnolo R, Dock-Nascimento DB, Aguilar-Nascimento JE. Espessura do músculo adutor do polegar como parâmetro antropométrico em pacientes críticos. Rev Bras Nutr Clin. [Internet]. 2010;25(3):1828 [Acesso 1 jun 2017]. Disponível em: http://www. sbnpe.com.br/wp-content/uploads/2016/12/02-Espessura-do-m\%C3\%BAsculo-adutor-do-polegar-comopar\%C3\%A2metro-antropom\%C3\%A9trico-em-pacientes-cr\%C3\%ADticos.pdf

26. Bielemann RM, Horta BL, Orlandi SP, Barbosa-Silva TG, Gonzalez MC, Assunção MC, et al. Is adductor pollicis muscle thickness a good predictor of lean mass in adults?
Clin Nutr. [Internet] 2015 [cited June 1, 2017];1-5. Available from: http://www.clinicalnutritionjournal.com/ article/S0261-5614(15)00201-0/pdf doi: http://dx.doi. org/10.1016/j.clnu.2015.07.022

27. Gonzalez MC, Duarte RR, Budziareck MB. Adductor pollicis muscle: reference values of its thickness in a healthy population. Clin Nutr. [Internet] 2010 [cited June 2, 2017];29(2):268-71. Available from: http:// www.clinicalnutritionjournal.com/article/S02615614(09)00176-9/pdf doi: http://dx.doi.org/10.1016/j. clnu.2009.08.012

28. Volpini MM, Frangella, VS. Avaliação nutricional de idosos institucionalizados. Einstein. [Internet]. 2013;11(1):32-40 [Acesso 1 jun 2017]. Disponível em: http://www.scielo.br/pdf/eins/v11n1/a07v11n1.pdf doi: http://dx.doi.org/10.1590/S1679-45082013000100007 29. Martinez EZ; Louzada-Neto F, Pereira BB. A curva de ROC para testes diagnósticos. Cad Saúde Coletiva. [Internet]. 2003;11(1):7-31 [Acesso 1 jun 2017]. Disponível em: http://www.po.ufrj.br/basilio/publicacoes/ artigos/2003_a_curva_ROC_para_testes_diagnosticos_ cadernos_saude_coletiva_vol11_JanJun.pdf
Copyright ( $) 2018$ Revista Latino-Americana de Enfermagem This is an Open Access article distributed under the terms of the Creative Commons (CC BY).

This license lets others distribute, remix, tweak, and build upon your work, even commercially, as long as they credit you for the original creation. This is the most accommodating of licenses offered. Recommended for maximum dissemination and use of licensed materials. 